\title{
Provosts' Perceptions of Academic Library Value and Preferences for Communication: A National Study
}

\author{
Adam Murray and Ashley Ireland
}

\begin{abstract}
While many studies have been conducted under the auspices of calculating academic library value, there are no large-scale studies into the perceptions that college or university provosts have of library value, nor are there studies into how provosts prefer library value data to be communicated. This study addresses that gap through a national survey of public and private university provosts/chief academic officers, with attention to size of the institution, accrediting agency, and the status of librarians at the institution. An understanding of provosts' perceptions of library value and preferences for communication aid library directors as they seek to leverage the findings of value studies for library advocacy.
\end{abstract}

\section{Introduction}

In his book Breakpoint, Jon McGee outlined the demographic, economic, and cultural transitions taking place in the United States and the significant impact those changes are having - and will continue to have - on higher education. ${ }^{1}$ He succinctly described the disruptions taking place in each of these three areas:

Demographic disruption: "That most students do not travel far to college raises the admission stakes associated with regional demographic trends. While demography may not be destiny, geographic choice patterns clearly influence market opportunity for most colleges and universities in the United States." ${ }^{2}$

Economic disruption: "As families wrestle with the diminished purchasing power of their incomes, it also remains to be seen how or if their spending and savings priorities will change as they consider college options for their children. Downward pressure on college price surely will continue in coming years; it is not simply a passing fad. Moreover, price anxiety just as surely will continue to move upward through higher and higher levels of family income as the price of college rises." ${ }^{3}$

\footnotetext{
*Adam Murray is Associate Professor and Dean of Libraries and Educational Technologies in the Carrier Library at James Madison University; e-mail: adammurray12@gmail.com. Ashley Ireland is Dean of University Libraries, Waterfield Library at Murray State University; e-mail: aireland@murraystate.edu. (C)2018 Adam Murray and Ashley Ireland, Attribution-NonCommercial (http://creativecommons.org/ licenses/by-nc/4.0/) CC BY-NC.
} 
Cultural disruption: "As higher education has expanded, reaching more people with more programs than ever before, it has become less discretely distinguishable, particularly as institutions of all types use similar language and images to describe who they are and what they do.... On the whole, colleges and universities most often look and act more alike than unalike."

These disruptions are accompanied by a host of consequences, ranging from local economic and workforce development concerns to state and federal oversight of higher education. Higher education leaders, including presidents and provosts, who have long grappled with the "iron triangle of higher education" (access, cost, quality), must now engage many different stakeholders-legislators, accreditors, faculty, parents, alumni, and students - in navigating a complex field of social disruptions to higher education. ${ }^{5}$ As discussed in an earlier study of provosts conducted by Beverly Lynch et al., library deans often struggle to communicate library value, particularly in an age where the academic library's rhetorical place as the "heart of the university" is no longer sufficient to garner additional resources-positions, funding, facilities - for the library. ${ }^{6}$ Being able to speak directly to library involvement in, and impact on, critical university initiatives such as enrollment, retention, student success, faculty research productivity, and accreditation is at the heart of the Association of College \& Research Libraries' Value of Academic Libraries and Assessment in Action initiatives. ${ }^{7}$ Academic librarians have conducted many studies using new methodologies and new data collection techniques to calculate the value of academic libraries. Determining the best ways to communicate those findings to institutional leaders, such as provosts or chief academic officers, has become an imperative next step. This study seeks to explore provosts' perceptions of academic library involvement with institutional initiatives, their preferences for communicating library impact, and the types of data that will make library budget requests more successful in the face of many competing priorities.

\section{Literature Review}

Demonstrating library value to university leaders, advocating for protected or additional resources, and positioning the library as a contributor to university initiatives are noted as being the responsibility of library deans or directors in a number of key articles in the library literature. Indeed, communicating value, advocating for library resources, and involving the library in university initiatives become-in a resourceconstrained and performance-based funding environment-a critical role for library leaders. Jody Fagan, who cited Weiner's 2003 literature review, highlighted that the "degree to which a university president commits adequate resources to the library is determined by his/her confidence in library leadership." 8 The role of library administrators was noted in Meagan Oakleaf's report, where she recommended that library deans not only support library assessment work but also work to communicate the findings of library value studies to university leaders and other stakeholders. ${ }^{9}$ In the study on the relationship between library assessment practices and student retention, Elizabeth Mezick stated:

\footnotetext{
"when presenting impact results to outside stakeholders, such as academic administrators or accreditation teams, care should be taken to avoid library jargon. Language used in institutional or higher education documents should be employed. Data and analysis should be organized and presented in ways that are meaningful for targeted audiences."10
} 
Despite the articulation of campus leadership roles for library deans or directors as seen by librarians, recognition by other administrators of the library dean's role as a university leader is limited. Barbara Dewey noted that position descriptions for library deans often omit the leadership role that library deans need to play on campus, particularly in informing the university strategic plan, curriculum and academic policy development, and space planning. ${ }^{11}$ There is the perception that provosts' knowledge of library issues is also limited. John Meier interviewed 44 Association of American Universities (AAU) library deans, with a focus on the future of academic libraries and library leadership. Meier indicated that:

"some respondents noted that their supervisor, often the university provost, was not knowledgeable about or concerned with library operations.... University administrators tend to be knowledgeable about issues of digital publishing and consider the library essential to researchers, rather than simply 'the heart of the university.'"12

In an age of increasing calls for higher education accountability, Meier indicated that "only three deans and university librarians (7 percent) described using data as a decision-making tool, employing either a strong program of assessment or checking a dashboard to analyze data." 13

Other studies on academic library leadership use organizational theories-such as Lee Bolman and Terrance Deal's four frameworks - as an analytical lens. ${ }^{14}$ Rachel Fleming-May and Kimberly Douglass used Bolman and Deal's four frameworks to explore tensions between librarians and the academy. ${ }^{15}$ They noted that, structurally and politically, librarians become support staff in disciplinary faculty's more autonomous work, manifesting in cultures of collaboration for librarians and competitive/solitary work for disciplinary faculty. ${ }^{16}$ Disciplinary faculty tend to view librarians as service providers and as separate educational agencies operating in a vague way that is not perceived as being connected to the teaching and research purposes of disciplinary faculty. FlemingMay recommended that library deans provide support to efforts by librarians to be more integrated into the teaching and research environment, and communicate with peers and institutional administration to "promote the library's contribution to the overall mission of the academic institution, especially in university's strategic planning."17

In a study of primary frames of library administrators in the Midwest, using Bolman and Deal's framework, Colleen Boff found that library administrators overwhelmingly rely on the human resources frame. ${ }^{18}$ Noting that Bolman and Deal's framework has been used in various studies in higher education, and the nature of the political and symbolic frames themselves, Boff suggested that library administrators will be more successful and serve longer terms in their administrations if they use a multiframe approach or prioritize the political and symbolic frames to "facilitate the significant shift away from traditional library work to newly imagined roles." ${ }^{19}$ She also noted that research into the perception of professionals who prioritize certain frames has established that "the structural frame is more indicative of behaviors associated with managers whereas the political and symbolic frames are more strongly associated with behaviors of effective leaders." 20

Clearly, it is important for library deans and directors to communicate regularly with provosts about library impact on initiatives of institutional importance and to do so using language and terms that are not library-centered but grounded in the lingua franca of higher education administration.

In their article "Attitudes of Presidents and Provosts on the University Library," Beverly Lynch et al. replicated a study conducted ten years prior and investigated the 
attitudes of university leaders toward libraries, using the "library as the heart of the university" metaphor. ${ }^{21}$ They found that, at some point in the ten years since the first study, the symbolic role of the library had shifted for administrators and that they were better able to support static funding, or even additional funding requests, if library administrators "employ strategies that connect what it does to the values and mission of the university." 22 The authors recommended highlighting the library's support of the "new indicators of centrality - such as innovation, campus visibility, and acquisition of outside funding" and then communicating them as a team member within the provost's council. They note the importance of multimodal communication and "to market and communicate this strategy verbally as well as with a written strategic plan aligned with the university's priorities."23

In their framework for developing reciprocal value propositions with the many different stakeholder groups of an academic library, the authors concluded that study was needed on provosts' perceptions of library value, their preferences for how library value data should be communicated to them, and what types of library value data will have the most impact on library funding. ${ }^{24}$ Aside from the study that Lynch et al. conducted, which itself used a focus group of a small number of provosts, there has been no large-scale, national study of provosts' perceptions of the academic library. This study seeks to fill that gap.

\section{Methodology}

Given the gap in library literature regarding provosts' perceptions of academic libraries, and particularly in light of the growing field of study surrounding academic library value, this study sought to explore three research questions:

1. How do provosts view academic libraries as playing a role in issues of institutional importance, such as high-impact practices impacting undergraduate retention?

2. What types of data would provosts find most likely to result in increased funding for academic library services and resources?

3. What methods of communication do provosts perceive as having the most impact on library funding requests?

This study used a survey of provosts/chief academic officers in the United States. The survey, available in appendix A, was constructed to solicit provosts' perceptions of academic library contributions to initiatives of institutional importance, along with their preferences for data (and communicating those data) with an impact on library funding requests. Prior to launching the survey, it was pilot-tested with a convenience sample of five provosts, associate provosts, and retired provosts with work histories that involved administrative work at institutions spanning all Carnegie classifications. Their feedback on the clarity of the questions, mechanisms for inputting responses, and the amount of time required to complete the survey were incorporated into the final instrument and informed consent documentation.

Participants in this study were provosts or chief academic officers at public and private (not-for-profit) colleges/universities with a Carnegie classification of master's or above, as of January 2016. Specifically, these categories included master's (small), master's (medium), master's (large), doctoral/research (DRU), research (RU/H), and research very high (RU/VH). The total population of provosts/CAOs was 937. Table 1 provides a summary of demographic information about the total population under study.

E-mail addresses for each individual provost/CAO were obtained from websites and web directories; institutions for which a viable e-mail address could not be located were eliminated from participation. Ultimately, the survey was distributed to 935 in- 
dividuals. The survey was active for one month, with weekly e-mail reminders. It was completed by 209 respondents, for a statistically significant response rate of 22 percent.

\begin{abstract}
Analysis
Initial analyses were completed by developing reports within Qualtrics that included number and percent of total response for each survey question. These descriptive statistics allowed for the identification of highest and lowest ranked responses for each question. Responses for specific survey questions were cross-tabulated with demographic information about the institution (enrollment, Carnegie classification, control, and accreditation region) to identify trends that conformed to or deviated from the overall set of responses. Chi squares were calculated using Qualtrics to determine if the relationships examined through cross-tabulations were statistically significant.
\end{abstract}

\title{
Results
}

Responses to the survey were analyzed for demographic information about survey respondents and their institutions, perceptions of involvement with university initiatives, and communication preferences.

\section{Demographic Information}

Of the respondents, 67 percent were from master's institutions $(28.93 \%$ small, $25 \%$ medium, and $12.69 \%$ large), with the remaining 33 percent coming from doctoral/ research $(11.68 \%)$, research high $(11.17 \%)$, and research very high $(11.17 \%)$ institutions. Institutions with fewer than 6,000 enrolled undergraduates made up the largest percent of respondents $(27.92 \%$ with 2,500 or fewer; $30.96 \%$ with $2,500-6,000)$. Respondents from institutions enrolling 6,000-12,000 students comprised 18.27 percent of the participant sample. The lowest percentage of respondents was from institutions with the highest undergraduate enrollment: institutions with an undergraduate enrollment of $12,000-18,000$ and with more than 18,000 comprised 10.66 percent and 12.18 percent of survey respondents, respectively. The respondents were symmetrically split between public and private control, with 50 percent of respondents coming from public institutions as well as from private institutions.

The survey also asked respondents to indicate their regional accrediting body, in the event that different regional accreditation requirements could impact provosts' perceptions of academic library value. Institutions within the North Central Association of Colleges and Schools-Higher Learning Commission (NCA-HLC) and the Southern Association of Colleges and Schools-Commission on Colleges (SACS-COC) comprised the highest number of respondents, with 35.53 percent and 31.47 percent of responses, respectively. These were followed by institutions within the Middle States Commission on Higher Education (MSCHE; 17.77\%), the Western Association of Schools and Colleges-Senior College and University Commission (WASC-SCUC; $6.60 \%$ ), the New England Association of Schools and Colleges Commission on Institutions of Higher Education (NEASC-CIHE; 5.58\%), and the Northwest Commission of Colleges and Universities (NWCCU; 3.05\%). These response rates roughly match the overall demographic information of the total population (see table 1); responses to survey questions therefore are not skewed toward or away from any given demographic variable.

Respondents were asked to indicate the faculty status of librarians at their institutions. Librarians are categorized as professional or classified staff at 52.38 percent of responding institutions, followed by faculty with eligibility for tenure at 40.48 percent, and faculty not eligible for tenure at 30.36 percent. Multiple answers were possible, as respondents were encouraged to "select all that apply." 


\begin{tabular}{|c|c|c|}
\hline \multicolumn{3}{|c|}{$\begin{array}{c}\text { TABLE } 1 \\
\text { Demographic Breakdown of Study Population }\end{array}$} \\
\hline & Total Study Population & Responses \\
\hline \multicolumn{3}{|l|}{ Institutional Control } \\
\hline Public & $448(47.81 \%)$ & $99(50.25 \%)$ \\
\hline Private (not for profit) & $489(52.19 \%)$ & $98(49.75 \%)$ \\
\hline \multicolumn{3}{|l|}{ Accreditation } \\
\hline Unknown & $11(1.17 \%)$ & No data \\
\hline National/Specialized & $5(0.53 \%)$ & No data \\
\hline State & $2(0.21 \%)$ & No data \\
\hline Middle States & $210(22.41 \%)$ & $35(17.77 \%)$ \\
\hline New England & $75(8.00 \%)$ & $11(5.58 \%)$ \\
\hline North Central & $278(29.67 \%)$ & $70(35.53 \%)$ \\
\hline Northwest & $47(5.02 \%)$ & $6(3.05 \%)$ \\
\hline Southern & $236(25.19 \%)$ & $62(31.47 \%)$ \\
\hline Western & $73(7.79 \%)$ & $13(6.60 \%)$ \\
\hline \multicolumn{3}{|l|}{ Carnegie Classification } \\
\hline Master's (small) & $101(10.78 \%)$ & $57(28.93 \%)$ \\
\hline Master's (medium) & $168(17.93 \%)$ & $48(24.37 \%)$ \\
\hline Master's (large) & $382(40.77 \%)$ & $25(12.69 \%)$ \\
\hline Doctoral/Research & $79(8.43 \%)$ & $23(11.68 \%)$ \\
\hline Research High & $99(10.57 \%)$ & $22(11.17 \%)$ \\
\hline Research Very High & $108(11.53 \%)$ & $22(11.17 \%)$ \\
\hline
\end{tabular}

\section{Involvement with University Initiatives}

The survey asked provosts to respond to how involved they perceived their institution's academic library to be in undergraduate retention initiatives, enrollment initiatives, student academic success, faculty research productivity, and accreditation. The highest percentage of provosts answered that they perceive the library to be "somewhat involved" with each of these institutional initiatives with the exception of enrollment, which received a slightly higher percentage as being "marginally involved." The highest areas of perceived involvement are faculty research productivity $(85.02 \%$ combined very involved/somewhat involved), accreditation $(82.15 \%$ combined very involved/somewhat involved), student academic success (75\% combined very involved/ somewhat involved), and undergraduate retention (67.26\% combined very involved/ somewhat involved). Only 9 percent of provosts thought the library was very involved with enrollment, with 35.71 percent rating them as having marginal involvement and 23.21 percent rating them as not involved.

Further analysis of responses to this question included cross-tabulation for current enrollment, Carnegie classification, and institutional control. Provosts at institutions with an enrollment of 12,000 or fewer rated their library as being somewhat involved in undergraduate retention initiatives, student academic success, faculty research productivity, and accreditation and marginally involved with enrollment initiatives. Provosts at institutions with an enrollment of 12,000 or more indicated higher involve- 
ment with accreditation, faculty research productivity, and student academic success. These provosts also rated their libraries as being somewhat involved in enrollment initiatives. Eleven provosts at institutions with more than 18,000 students indicated that their institution's library was very involved with undergraduate retention. These trends were also evident when responses to this question were cross-tabulated with Carnegie classification. Provosts at institutions with a classification of master's (small, medium, or large) tended to rate library involvement with faculty research productivity, student academic success, and undergraduate retention as "somewhat involved," while they rated the library as being marginally involved with enrollment initiatives. Provosts at DRU and RU/VH institutions tended to rate their institutions' libraries as being very involved in retention initiatives, student academic success, and faculty research productivity, and somewhat involved with accreditation and enrollment. Provosts at public institutions rated their institutions' library involvement with retention and student academic success as being somewhat involved. With regard to enrollment initiatives, provosts at public institutions evenly rated libraries as being somewhat or marginally involved. They rated libraries as being very involved in faculty research productivity and accreditation. Provosts at private institutions, however, rated their institutions' libraries as being somewhat involved in faculty research productivity, accreditation, retention, enrollment, and student academic success.

When asked why provosts did not view their institutions' academic libraries as being involved with undergraduate retention initiatives, provosts overwhelmingly indicated that it was because the campuses overall did not recognize the role the libraries could play in retention initiatives $(76.12 \%)$. This was followed by the library being short-staffed (28.36\%) and the library dean having not prioritized library participation in retention $(16.42 \%)$. This trend held when the responses were cross-tabulated with current enrollment, Carnegie classification, and public/private institutions.

The ten high-impact educational practices (HIPs) identified by George Kuh served as a framework for examining provosts' perceptions of library involvement in educationally purposeful activities that have an impact on student academic and social integration (and thus on retention, completion, and success). ${ }^{25}$ Provosts were asked to rate how involved they perceived their institution's academic library to be in first-year seminars and first-year experiences, common intellectual (curricular or cocurricular) experiences, learning communities, writing-intensive courses, collaborative assignments and projects, undergraduate research, diversity and global learning, service learning and community-based learning, internships, and capstone courses and projects. Of the ten, provosts rated their institutions' libraries as being very involved or somewhat involved with six HIPs. First among these was undergraduate research $(84.43 \%$ combined very involved/somewhat involved), followed by first-year seminars/experiences (78.39\% combined very involved/somewhat involved), collaborative assignments and projects (77.38\% combined very involved/somewhat involved), writing-intensive courses (75.76\% combined very involved/somewhat involved), common intellectual experiences (71.34\% combined very involved/somewhat involved), and capstone courses/projects (69.64\% combined very involved/somewhat involved). Provosts rated libraries as being less involved with diversity and global learning and learning communities. Sixtyseven percent of responding provosts rated libraries as being somewhat or marginally involved in diversity and global learning, while 60.59 percent of responding provosts rated libraries as being somewhat or marginally involved with learning communities. Service-learning and internships received the lowest ratings. Of the responding provosts, 84.85 percent rated their institutions' academic libraries as being somewhat, marginally, or not involved with service learning or community-based learning, a percentage that rose to 90.24 percent for somewhat/marginal/not involved with internships. 
Overall, provosts at public institutions and provosts at private institutions had similar perceptions of library involvement with HIPs, with a few exceptions. Fortyeight percent of responding provosts at public institutions rated the library as being somewhat involved with undergraduate research, while 46 percent of provosts at private institutions rated the library as being very involved. Provosts at private institutions also rated the library as being more involved with learning communities $(65 \%$ combined somewhat and very involved ratings) than did their counterparts at public institutions (52\% combined somewhat and very involved ratings). However, private institution provosts viewed the library as being less involved with service learning than did provosts at public institutions $(62 \%$ combined marginal or no involvement rating at private institutions compared to $47 \%$ combined marginal or no involvement rating at public institutions). The Chi Square for these trends not to reveal any statistical significance.

When asked if their institution's academic library had an impact on students' decisions to continue enrollment at their university, provosts were divided. Of those who affirmed the library's impact on retention, 36.53 percent made this judgment based on anecdotal or suspected evidence, while 17.96 percent based this judgment on demonstrated evidence. Fully one-third of the responding provosts $(34.73 \%)$ indicated that it was unclear whether their institutions' academic libraries had an impact on retention, while 13.77 percent indicated that their libraries did not have an impact on retention. These percentages held regardless of whether the provost was at a public or private institution. However, provosts at institutions of different sizes had different responses than the overall trends, as seen in table 2, and visualized in figure 1.

\begin{tabular}{|l|c|c|c|c|c|}
\hline \multicolumn{7}{|c|}{ TABLE 2} \\
\begin{tabular}{|} 
Responses to "In your view, does your institution's academic library have \\
an impact on students' decisions to continue enrollment?" (N = 167)
\end{tabular} \\
\hline & $\begin{array}{c}\mathbf{2 , 5 0 0} \\
\text { or } \\
\text { fewer }\end{array}$ & $\begin{array}{c}\mathbf{2 , 5 0 0}- \\
\mathbf{6 , 0 0 0}\end{array}$ & $\begin{array}{c}\mathbf{6 , 0 0 0}- \\
\mathbf{1 2 , 0 0 0}\end{array}$ & $\begin{array}{c}\mathbf{1 2 , 0 0 0}- \\
\mathbf{1 8 , 0 0 0}\end{array}$ & $\begin{array}{c}\text { More } \\
\text { than } \\
\mathbf{1 8 , 0 0 0}\end{array}$ \\
\hline Yes, based on demonstrated evidence & 4 & 12 & 9 & 1 & 4 \\
& $8.70 \%$ & $24.49 \%$ & $27.27 \%$ & $5.88 \%$ & $18.18 \%$ \\
\hline Yes, based on anecdotal or suspected & 18 & 14 & 9 & 10 & 10 \\
evidence & $39.13 \%$ & $28.57 \%$ & $27.27 \%$ & $58.82 \%$ & $45.45 \%$ \\
\hline Unclear & 19 & 18 & 10 & 5 & 6 \\
& $41.30 \%$ & $36.73 \%$ & $30.30 \%$ & $29.41 \%$ & $27.27 \%$ \\
\hline No & 7 & 7 & 5 & 1 & 3 \\
& $15.22 \%$ & $14.29 \%$ & $15.15 \%$ & $5.88 \%$ & $13.64 \%$ \\
\hline
\end{tabular}

Provosts at institutions with an enrollment of 12,000 or more provided a higher rating of library impact on retention, based on anecdotal or suspected evidence, than did provosts at institutions of 12,000 or fewer. Likewise, as the size of the institution increased, the rating of "unclear" also decreased, though, with a $P$-value of .37, this relationship is not statistically supported. Many of these differences from the average were also demonstrated when responses were cross-tabulated with Carnegie classification. Provosts at master's (small), DRU, RU/H, and RU/VH institutions provided higher than average perceptions that the library has an impact on retention, based on anecdotal or suspected evidence, while provosts at medium and large master's institutions provided lower than average ratings. Fifty percent of the provosts at master's 


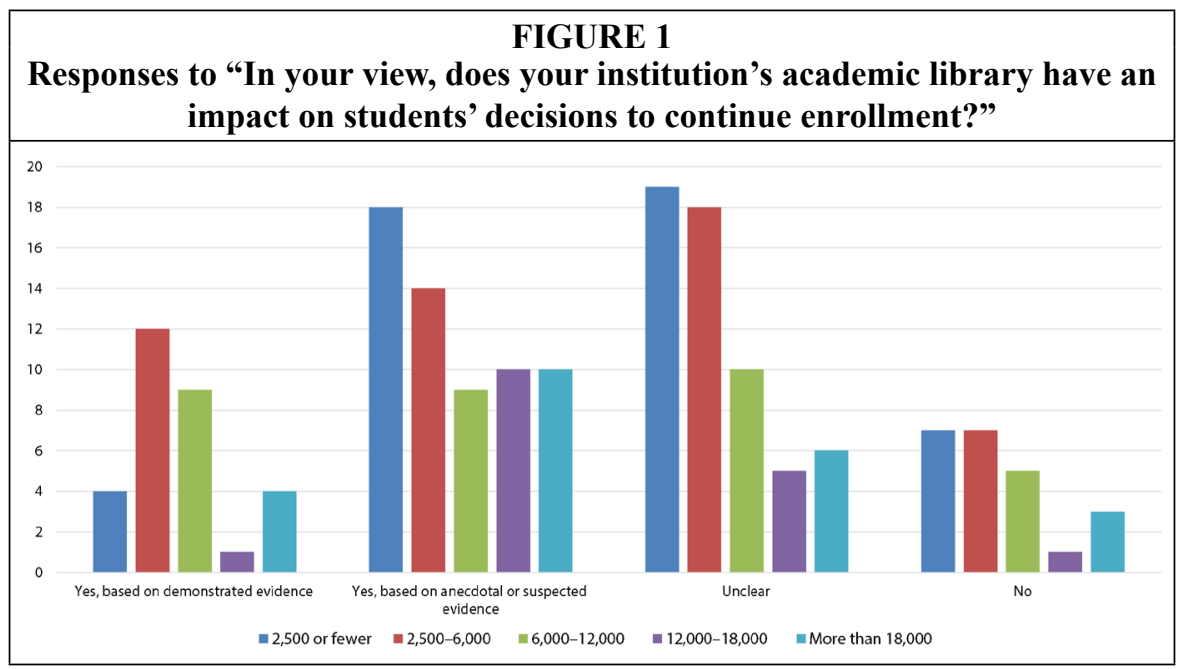

large and RU/H institutions indicated that it was unclear if the library had any impact on retention, while these provosts also provided the lowest rating of library impact on retention, based on demonstrated evidence (5\%). As with enrollment, the relationship between Carnegie classification and responses to this question were not statistically supported, with a $P$-value of .40 .

Of the respondents, 99 provosts (59\%) indicated a perception that their institution's academic library was marginally involved or not involved with enrollment initiatives. Just over half of these respondents were from institutions with a Carnegie classification of master's small or master's medium, 15 percent at master's large, and 10 percent each for DRU, RU/H, and RU/VH. Most of these institutions have an enrollment of 6,000 or fewer $(62 \%)$, with slightly more private institutions than public ( $54 \%$ vs. $45 \%)$. At these institutions, librarians are predominantly considered staff. Provosts who indicated a perception of their institution's academic library as marginally or not involved with enrollment initiatives also consistently indicated some or marginal involvement by the library in undergraduate retention initiatives and student academic success, but rated involvement with faculty research productivity and accreditation slightly more favorably. These respondents overwhelmingly $(79.66 \%)$ indicated that the reason the library is not involved with undergraduate retention initiatives is "because the campus overall does not recognize the role the library could play in retention initiatives," in keeping with the ratings provided by all respondents. However, these respondents were much less consistent in their perceptions of library involvement with the HIPs, with ratings ranging across all levels of involvement for each HIP.

Of the total respondents, eighteen $(10 \%)$ indicated a perception that their institution's academic library is not involved with undergraduate retention initiatives. These respondents were fairly equally distributed across Carnegie classifications, with eight of them being at institutions with an enrollment between 2,500 and 6,000. These respondents were from slightly more public institutions than private (55\% vs. $44 \%$ ). Fully 50 percent of these respondents were from the North Central accreditation region, exceeding the overall sample population from this accreditation region. Librarians at these institutions tend to be categorized as either staff or faculty without eligibility for tenure. These eighteen provosts also tended to view the library as not involved with enrollment initiatives (88.89\%), and marginally or not involved with student academic success (combined 64\%). They did rate their library as having more involvement with 
faculty research productivity (38\% very involved; $27 \%$ somewhat involved), with 44 percent indicating that the library was somewhat involved with accreditation. A slightly higher percentage of these provosts $(82 \%)$ indicated that the campus overall did not recognize the role the library could play in retention initiatives as a reason for lack of library involvement with retention than did the overall population $(79 \%)$. These provosts also tended to view the library as being marginally or not involved with first-year seminars, common intellectual experiences, learning communities, writing-intensive courses, diversity and global learning, service learning, internships, and capstone courses. Collaborative assignments and projects and undergraduate research were rated slightly higher, with 38 percent of these respondents indicating that the library was somewhat involved with these two HIPs. When asked whether their institution's academic library has an impact on students' decisions to continue enrollment, 44 percent responded "unclear" and 44 percent responded "no."

Of the respondents, $64(38.10 \%)$ indicated a perception that the academic library was very involved with accreditation. The majority of these provosts (58\%) were at master's small or master's medium institutions, primarily with enrollments of 6,000 or fewer. However, 20 percent were at institutions with an enrollment of 18,000 or more, which is more than the overall population percentage. Sixty percent of these responding provosts were at public institutions, and these respondents were mostly from the NCA-HLC $(40.63 \%)$ or SACS-COC (29.69\%) accreditation regions. This geographic distribution reflects the overall population of survey respondents; it was not noticeably higher or lower than the overall response for this question. Unlike the overall set of responses, a majority of the provosts who saw their library as being very involved with accreditation indicated that librarians at their institutions are categorized as faculty with eligibility for tenure $(51.56 \%)$. These provosts also rated their library as being very involved with student academic success $(51.56 \%)$ and faculty research productivity $(53.97 \%)$ and somewhat involved with undergraduate retention initiatives and enrollment initiatives $(42.19 \%$ each). These ratings were higher than those given by the overall set of respondents. They also tended to rate their library as being very or somewhat involved with all but three of the HIPs. The three HIPs with lower ratings were service learning, internships, and capstone courses, which also tended to have lower ratings of involvement by the overall population. These 64 provosts overwhelmingly indicated their belief that the library has an impact on students' decisions to continue enrollment, based on anecdotal or suspected evidence (51.56\%), with an additional 28.13 percent based on demonstrated evidence.

\section{Communicating Library Value}

The final set of questions gathered data about provosts' perspectives on data to support funding requests, as well as their preferences for how those data should be communicated to them.

Provosts were asked to rate the amount of influence (no influence, low influence, moderate influence, or high influence) of eleven different data on a moderate (noncapital) funding request for the library. The eleven different types of data provosts were asked to rate were basic use data (such as door counts or download counts); user satisfaction data; faculty feedback; endorsement of the request by other deans, directors, or administrators; demonstrated correlations linking use of library services/ resources to undergraduate retention, enrollment, student success, and faculty research productivity; focus groups or other qualitative data; anecdotal evidence; and information literacy student learning outcome assessment data. The types of data with the highest influence on a funding request (meaning the provost would prioritize the request over others) were demonstrated correlations linking use of library services/ 
resources with student academic success (72.02\%), demonstrated correlations linking use of library services/resources with undergraduate retention $(66.07 \%)$, demonstrated correlations linking use of library services/resources with enrollment (56.55\%), demonstrated correlations linking use of library services/resources with faculty research productivity $(47.62 \%)$, and endorsement of the request by other deans, directors, or administrators (also at $47.62 \%$ ).

Provosts rated other types of data as having moderate influence on a funding request (meaning they would consider prioritizing the request). Chief among these were basic use data $(57.14 \%)$, user satisfaction data $(55.36 \%)$, focus groups or other qualitative data $(50.00 \%)$, information literacy student learning outcome (SLO) assessment data (48.21\%), and faculty feedback (45.24\%). Faculty feedback, information literacy SLO assessment data, and user satisfaction data also had a proportion of respondents that noted these types of data as having high influence (faculty feedback: $42.86 \%$; information literacy SLO assessment data: $38.10 \%$; user satisfaction data: $27.38 \%$ ).

None of the data types received a top rating of no influence. However, anecdotal evidence was rated by 60.12 percent of responding provosts as low influence (meaning they would probably not prioritize a funding request based on these data) and by 27.38 percent as having no influence.

Responses for this question were cross-tabulated with both Carnegie classification and institutional control. There were no notable differences from the average ratings between public and private institutions, though provosts at public institutions did provide a slightly greater rating of "high influence" for faculty research productivity (public: $54.76 \%$; private $40.48 \%$; overall $47.62 \%$ ). There were also no notable differences from overall ratings for use data, user satisfaction, faculty feedback (with one exception: public university provosts had a slightly higher rating of "high influence" for faculty feedback than did their counterparts at private institutions), and anecdotal evidence when cross-tabulated by institutional control. However, there were several notable differences from the overall ratings contained in the Carnegie classification cross-tabulation (see table 3 ).

Provosts at master's institutions had nearly equivalent high and moderate ratings for endorsement of a request by other deans or administrators; however, provosts at DRU and $\mathrm{RU} / \mathrm{H}$ institutions rated endorsement more highly, with 64.71 percent and 72.73 percent respectively, indicating that these types of data had high influence on a funding request. Provosts at DRU institutions provided higher than overall ratings of "high influence" for several types of data: demonstrated correlations with undergraduate retention (82.35\%), faculty feedback $(70.59 \%)$, demonstrated correlations with student academic success (88.24\%), and demonstrated correlations with faculty research productivity $(76.47 \%)$. Provosts at RU/H institutions also rated demonstrated correlations with faculty research productivity higher than the overall, at 68.18 percent. To contrast, only 26.09 percent of the provosts at small master's institutions rated demonstrated correlations with faculty research productivity as "high influence." Provosts at DRU institutions also provided a higher than average rating for focus group data as having a moderate influence on a funding request $(70.59 \%)$, while provosts at master's small institutions tended to rate focus group data as low influence $(39.13 \%)$ or moderate influence $(36.96 \%)$. Provosts at medium master's institutions provided a higher than average rating of information literacy student learning outcome data as having a high influence on a funding request (48\%).

The survey's final question asked provosts to indicate what they thought would be the most effective way for library deans to communicate various types of data with them in a way that would most likely improve library funding. Respondents could prioritize five communication methods (formal annual report, annual budget presentation, e-mail, presentation or meeting, or these types of data have little influence on 


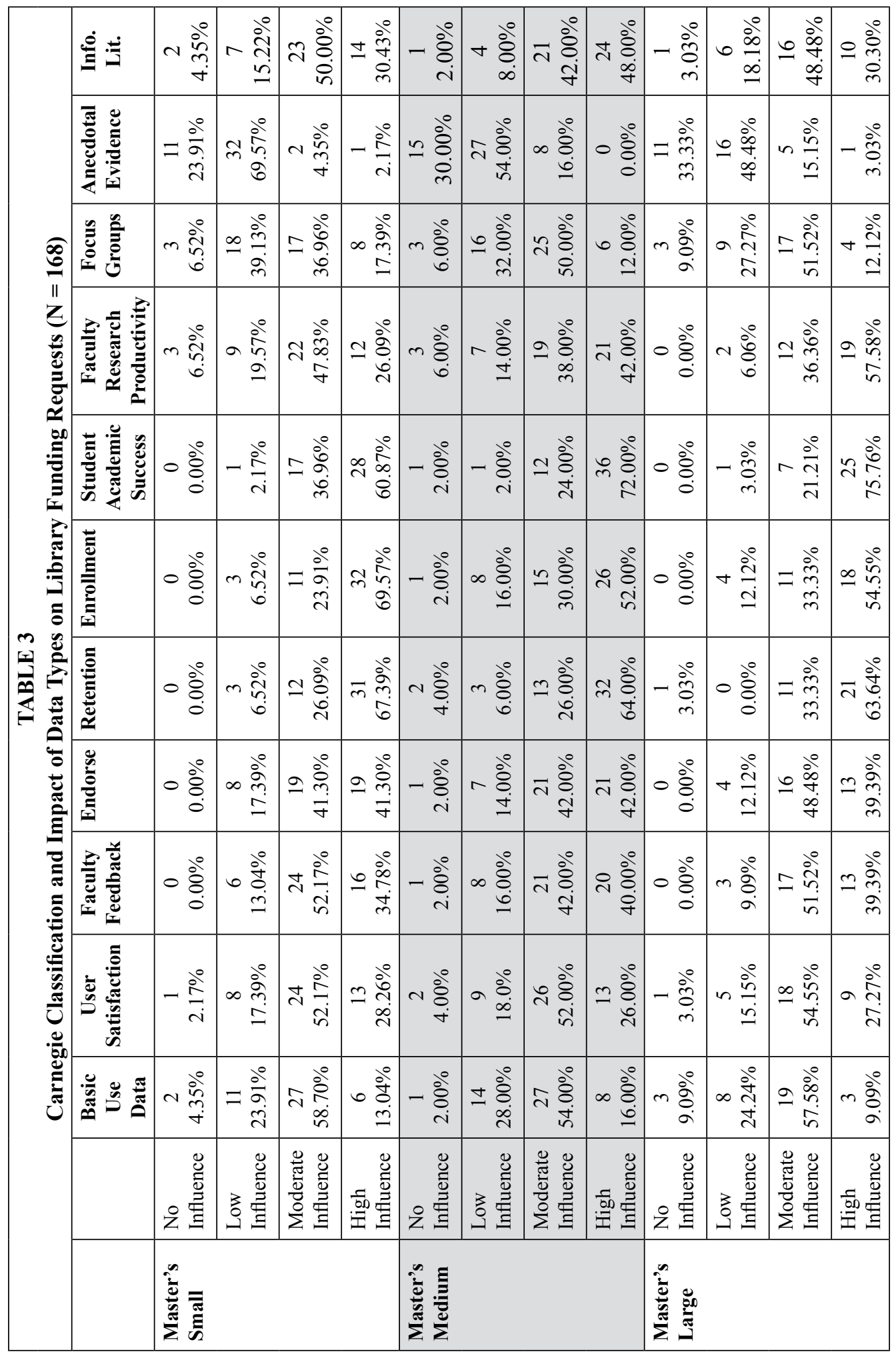




\begin{tabular}{|c|c|c|c|c|c|c|c|c|c|c|c|}
\hline ○ & $\begin{array}{r}\infty \\
-\infty \\
\infty \\
\infty\end{array}$ & 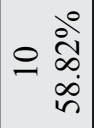 & $\begin{array}{ll}0 & \stackrel{\circ}{2} \\
\text { ñ }\end{array}$ & $0 \stackrel{\circ}{8}$ & $-\stackrel{i}{i n}$ & $=\frac{80}{8}$ & $0 \underset{\frac{i}{5}}{\stackrel{i}{f}}$ & $\begin{array}{r}\stackrel{0}{\infty} \\
\text { ñ } \\
\text { N }\end{array}$ & aㄹ & $\bar{\infty} \frac{0^{\circ}}{\stackrel{\infty}{\sim}}$ & 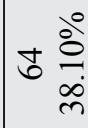 \\
\hline n $\frac{\partial ゚}{\partial}$ & 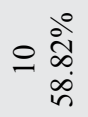 & $\begin{array}{r}\infty \\
-\infty \\
-\infty \\
\infty \\
i\end{array}$ & $\begin{array}{r}0 \\
-\infty \\
-\infty \\
\infty \\
\dot{1}\end{array} \mid$ & $+\frac{\stackrel{\infty}{\infty}}{\stackrel{\infty}{\infty}}$ & $\stackrel{\stackrel{\circ}{i}}{\stackrel{i}{i}}$ & v $\stackrel{\circ}{\circ}$ & ○ $\frac{\dot{0}}{0}$ & 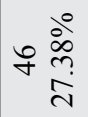 & $=\frac{\stackrel{\circ}{ }}{\stackrel{0}{0}}$ & $\infty \frac{0^{\circ}}{0}$ & m ㅇํ ำ \\
\hline 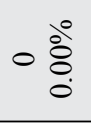 & 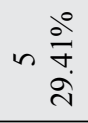 & 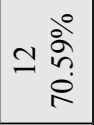 & $\begin{array}{ll}0 & 8 \\
0 & 8 \\
& 0 \\
& 0\end{array}$ & 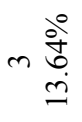 & 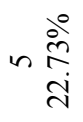 & 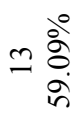 & - $\underset{i}{\stackrel{i}{n}}$ & $\simeq \stackrel{\stackrel{\circ}{ \pm}}{\frac{D}{T}}$ & n $\frac{\stackrel{i}{n}}{n}$ & 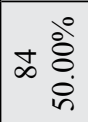 & $a \stackrel{\circ}{\stackrel{0}{\varrho}}$ \\
\hline ○ & 0 & $\begin{array}{r}\stackrel{0}{n} \\
\ddot{n} \\
\ddot{n}\end{array}$ & $=\underset{\frac{2}{7}}{\stackrel{0}{0}}$ & ○ & $-\stackrel{\stackrel{\circ}{n}}{\stackrel{n}{+}}$ & $0 \underset{\frac{N}{N}}{\stackrel{2}{N}}$ & $\backsim \frac{\dot{\infty}^{\circ}}{\infty \dot{0}}$ & $0 \stackrel{\frac{0}{n}}{n}$ & $a \stackrel{0^{\circ}}{=}$ & & 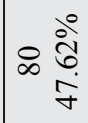 \\
\hline ○ & 0 & 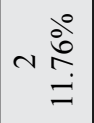 & $\because \underset{\substack{+\infty}}{\stackrel{0}{+}}$ & ○ & $-\stackrel{\stackrel{\circ}{\circ}}{\stackrel{i}{+}}$ & $+\frac{\infty}{\stackrel{\infty}{\infty}}$ & $=\underset{\frac{0}{N}}{\stackrel{0}{i}}$ & - & 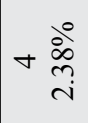 & 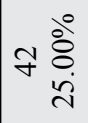 & 긍 \\
\hline ○ & 0 & م每 & $\begin{array}{ll}0 & \stackrel{0}{N} \\
- & \infty \\
& \infty \\
& \infty\end{array}$ & 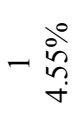 & 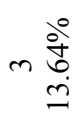 & $a \frac{\partial}{a}$ & $a \frac{\partial}{a}$ & 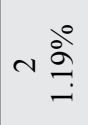 & $\infty \frac{0^{\circ}}{\hat{\sigma}}$ & m $\frac{i^{n}}{n}$ & 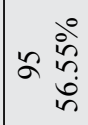 \\
\hline o & 0 & m $\begin{array}{l}\text { iñ } \\
\text { ọ } \\
\text { N }\end{array}$ & 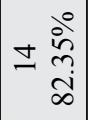 & $-\stackrel{i n}{i n}$ & ○ & $\infty \underset{\substack{0 \\
0}}{\stackrel{0}{0}}$ & $=\frac{\stackrel{\circ}{\circ}}{\dot{\sigma}}$ & $\nabla \underset{\substack{\infty\\
}}{\stackrel{0}{i}}$ & $0 \underset{n}{\stackrel{0}{n}}$ & 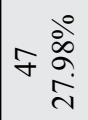 & $=\frac{\stackrel{0}{0}}{0}$ \\
\hline o $\begin{array}{l}0 \\
0 \\
0 \\
0\end{array}$ & 0 & 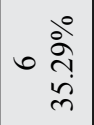 & $=\frac{\stackrel{\partial}{7}}{\underset{0}{0}}$ & $0 \stackrel{8}{0}$ & $-\stackrel{\stackrel{\circ}{n}}{\stackrel{n}{+}}$ & 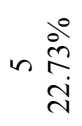 & $\stackrel{\circ}{\stackrel{\stackrel{9}{2}}{i}}$ & - & ঃ & $\begin{array}{l}\hat{\sigma} \\
\stackrel{0}{\infty} \\
\text { mे } \\
\text { mे }\end{array}$ & 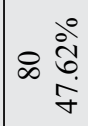 \\
\hline ○ & 0 ${ }_{0}^{\circ} \stackrel{0}{0}$ & n $\begin{array}{l}\frac{\partial}{\nabla} \\
\stackrel{े}{\sigma}\end{array}$ & 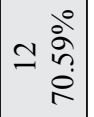 & $0 \stackrel{8}{\circ}$ & N $\stackrel{\circ}{\circ}$ & $a \frac{\partial}{a}$ & $=\frac{\dot{0}_{0}^{\circ}}{\dot{8}}$ & - & $a \frac{0^{\circ}}{\equiv}$ & 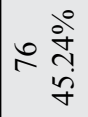 & 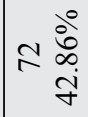 \\
\hline 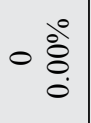 & $\begin{array}{r}-\infty \\
-\infty \\
\infty \\
\infty \\
i\end{array}$ & 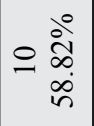 & $\begin{array}{ll}0 & \stackrel{\circ}{2} \\
\text { ñ் } \\
\text { ñ }\end{array}$ & ○ & v & $\sim \frac{\dot{\infty}^{\circ}}{\frac{\dot{\infty}}{\dot{0}}}$ & 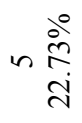 & 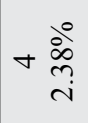 & 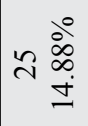 & 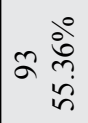 & 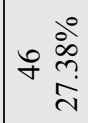 \\
\hline o & 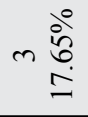 & $=\frac{\partial^{\circ}}{\nabla}$ & 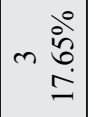 & - $\stackrel{\stackrel{i}{n}}{\stackrel{+}{+}}$ & 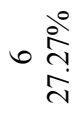 & $\simeq \stackrel{\stackrel{\circ}{n}}{\stackrel{n}{n}}$ & $m \underset{\stackrel{0}{\stackrel{+}{0}}}{\stackrel{0}{0}}$ & $\sim \stackrel{\stackrel{2}{二}}{ت}$ & 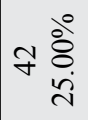 & 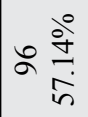 & ๗ \\
\hline ○ & 兽 & 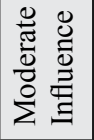 & 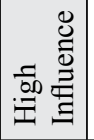 & 之욜 & 泀 & 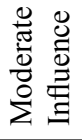 & 总 & 乙 & 导 & 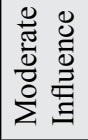 & \\
\hline 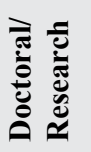 & & & & \multicolumn{4}{|l|}{ 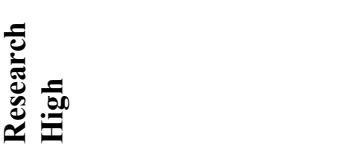 } & \multicolumn{4}{|l|}{ 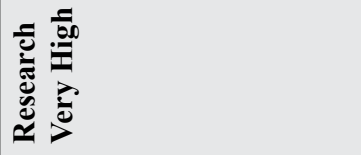 } \\
\hline
\end{tabular}


library funding) for each of ten types of data (basic use data; user satisfaction data; faculty feedback; endorsement of the request by other deans/directors/administrators; demonstrated correlations linking use of library services/resources with undergraduate retention, enrollment, student success, and faculty productivity, qualitative or anecdotal data; and information literacy student learning outcome assessment data).

The formal annual report was selected by the majority of respondents as the top method of communicating in a way that improved library funding for eight of the types of data. These eight types of data were information literacy SLOs (50.90\%), user satisfaction data $(46.11 \%)$, correlations with faculty productivity $(45.45 \%)$, correlations with student success $(44.91 \%)$, correlations with undergraduate retention $(43.11 \%)$, correlations with enrollment $(42.51 \%)$, basic use data $(40.12 \%)$, and faculty feedback $(39.10 \%)$. Communication preferences for these eight types of data were consistent for provosts' second and third choices, with a presentation or meeting being the second choice, followed by the annual budget presentation.

The two types of data with divergent trends of preferred communication methods were "endorsement of the request by other deans, directors, or administrators" and "qualitative or anecdotal data." Responding provosts preferred endorsement of a budget request by other administrators to be communicated in a presentation or meeting $(32.53 \%)$, by e-mail $(25.3 \%)$, in an annual budget presentation $(22.29 \%)$, and via the formal annual report (16.27\%). For qualitative or anecdotal data, 28.14 percent of responding provosts indicated that these types of data had little influence on improving library funding, followed by a preference for this information to be communicated in a presentation or meeting $(21.56 \%)$, by e-mail $(20.36 \%)$, in a formal annual report $(19.76 \%)$, and via an annual budget presentation $(10.18 \%)$.

When responses to this question were cross-tabulated with institutional control, there were notable (though not statistically significant) differences between the communication preferences of provosts at public institutions and provosts at private institutions. Provosts at public institutions tended to prefer demonstrated correlations between library services and undergraduate retention, enrollment, student academic success, faculty research productivity, and information literacy SLO data to be communicated through the formal annual report, while provosts at private institutions tended to prefer

\begin{tabular}{|c|c|c|c|c|c|c|}
\hline \multicolumn{7}{|c|}{$\begin{array}{c}\text { TABLE } 4 \\
\text { Communication of Endorsement of a Library Budget Request by Other } \\
\text { Deans, Directors, or Administrators }(\mathrm{N}=166)\end{array}$} \\
\hline & $\begin{array}{c}\text { Master's } \\
\text { Small }\end{array}$ & $\begin{array}{l}\text { Master's } \\
\text { Medium }\end{array}$ & $\begin{array}{c}\text { Master's } \\
\text { Large }\end{array}$ & Doctoral & $\begin{array}{c}\text { Research } \\
\text { High }\end{array}$ & $\begin{array}{l}\text { Research } \\
\text { Very High }\end{array}$ \\
\hline $\begin{array}{l}\text { Formal Annual } \\
\text { Report }\end{array}$ & $\begin{array}{c}6 \\
13.33 \% \\
\end{array}$ & $\begin{array}{c}5 \\
10.00 \%\end{array}$ & $\begin{array}{c}7 \\
21.88 \%\end{array}$ & $\begin{array}{c}3 \\
17.65 \%\end{array}$ & $\begin{array}{c}6 \\
27.27 \%\end{array}$ & $\begin{array}{c}27 \\
16.27 \%\end{array}$ \\
\hline $\begin{array}{l}\text { Annual Budget } \\
\text { Presentation }\end{array}$ & $\begin{array}{c}10 \\
22.22 \%\end{array}$ & $\begin{array}{c}8 \\
16.00 \% \\
\end{array}$ & $\begin{array}{c}9 \\
28.13 \% \\
\end{array}$ & $\begin{array}{c}3 \\
17.65 \% \\
\end{array}$ & $\begin{array}{c}7 \\
31.82 \% \\
\end{array}$ & $\begin{array}{c}37 \\
22.29 \% \\
\end{array}$ \\
\hline E-mail & $\begin{array}{c}8 \\
17.78 \% \\
\end{array}$ & $\begin{array}{c}18 \\
36.00 \% \\
\end{array}$ & $\begin{array}{c}6 \\
18.75 \% \\
\end{array}$ & $\begin{array}{c}6 \\
35.29 \% \\
\end{array}$ & $\begin{array}{c}4 \\
18.18 \% \\
\end{array}$ & $\begin{array}{c}42 \\
25.30 \% \\
\end{array}$ \\
\hline $\begin{array}{l}\text { Presentation or } \\
\text { meeting }\end{array}$ & $\begin{array}{c}19 \\
42.22 \%\end{array}$ & $\begin{array}{c}15 \\
30.00 \% \\
\end{array}$ & $\begin{array}{c}10 \\
31.25 \% \\
\end{array}$ & $\begin{array}{c}5 \\
29.41 \% \\
\end{array}$ & $\begin{array}{c}5 \\
22.73 \% \\
\end{array}$ & $\begin{array}{c}54 \\
32.53 \% \\
\end{array}$ \\
\hline $\begin{array}{l}\text { This type of data } \\
\text { has little influence } \\
\text { on improving } \\
\text { library funding }\end{array}$ & $\begin{array}{c}2 \\
4.44 \%\end{array}$ & $\begin{array}{c}4 \\
8.00 \%\end{array}$ & $\begin{array}{c}0 \\
0.00 \%\end{array}$ & $\begin{array}{c}0 \\
0.00 \%\end{array}$ & $\begin{array}{c}0 \\
0.00 \%\end{array}$ & $\begin{array}{c}6 \\
3.61 \%\end{array}$ \\
\hline
\end{tabular}


these data to be communicated through presentations or meetings. There were no notable differences between public and private institutions with regard to communication preferences for basic use data, user satisfaction data, faculty feedback, endorsement of a request by other deans, directors, or administrators, and qualitative/anecdotal data.

Responses for this question were also consistent when cross-tabulated for Carnegie classification. However, this was not the case for one data type: endorsement of a budget request by other deans, directors, or administrators. Table 4 highlights the wide distribution of responses for this question.

Finally, responses for the two questions on communicating library value were cross-tabulated with accreditation region. No notable trends were observed; however, provosts in the New England Association of Schools and Colleges did have some differences from their peers in other accreditation regions. These provosts were more likely to view their academic library as being very involved in undergraduate retention (57.14\%) and to indicate their perspective that the library has an impact on students' decisions to remain enrolled based on demonstrated evidence (42.86\%). No provost in this accreditation region found basic use data to have high influence on a budget request (the only accreditation region to have a $0 \%$ response to this data element).

\section{Discussion}

These findings, overall, demonstrate the need for continued effort to link library services and resources to initiatives of institutional priority. Provosts tended to rate the academic library as being "somewhat involved" with institutional initiatives such as retention, student academic success, and faculty productivity, and less involved with enrollment. A perception that the library has less involvement with enrollment, in the face of arguments that attractive and cutting-edge library facilities can contribute to students' and parents' decisions on applying to universities, is troubling. The overwhelming response by provosts that their campuses overall do not recognize the role the library can play in retention initiatives is likewise evidence of the continued work librarians and library directors need to do in making these connections in a way that is visible to faculty and administrators.

It should come as no surprise that provosts at all types of institutions perceive use data and user satisfaction data to have only moderate impact on a funding decision, though there is value in seeing this perspective confirmed.

Librarians at different types of institutions may look for clear trends among provosts from their types of institutions. This section provides a broad overview based on trends that surface when isolating control, size, and various accrediting agency affiliation variables. See tables 5 and 10 for summaries of these trends.

\begin{tabular}{|c|c|}
\hline \multicolumn{2}{|c|}{$\begin{array}{c}\text { TABLE } 5 \\
\text { Perception of Library Involvement with Undergraduate Retention }(\mathrm{N}=168)\end{array}$} \\
\hline & Responses \\
\hline \multicolumn{2}{|l|}{ Enrollment } \\
\hline 2,500 or fewer & $\begin{array}{l}\text { Very Involved: } 17.39 \% \\
\text { Somewhat Involved: } 54.35 \% \\
\text { Marginally Involved: } 21.74 \% \\
\text { Not Involved: } 6.52 \%\end{array}$ \\
\hline $2,500-6,000$ & $\begin{array}{l}\text { Very Involved: } 16.00 \% \\
\text { Somewhat Involved: } 40.00 \% \\
\text { Marginally Involved: } 28.00 \% \\
\text { Not Involved: } 16.00 \%\end{array}$ \\
\hline
\end{tabular}




\begin{tabular}{|c|c|}
\hline \multicolumn{2}{|c|}{$\begin{array}{c}\text { TABLE } 5 \\
\text { Perception of Library Involvement with Undergraduate Retention }(N=168)\end{array}$} \\
\hline $6,000-12,000$ & $\begin{array}{l}\text { Very Involved: } 24.24 \% \\
\text { Somewhat Involved: } 48.48 \% \\
\text { Marginally Involved: } 21.21 \% \\
\text { Not Involved: } 6.06 \%\end{array}$ \\
\hline $12,000-18,000$ & $\begin{array}{l}\text { Very Involved: } 35.29 \% \\
\text { Somewhat Involved: } 47.06 \% \\
\text { Marginally Involved: } 5.88 \% \\
\text { Not Involved: } 11.76 \%\end{array}$ \\
\hline More than 18,000 & $\begin{array}{l}\text { Very Involved: } 50.00 \% \\
\text { Somewhat Involved: } 13.64 \% \\
\text { Marginally Involved: } 22.73 \% \\
\text { Not Involved: } 13.64\end{array}$ \\
\hline \multicolumn{2}{|c|}{ Carnegie Classification } \\
\hline Master's Small & $\begin{array}{l}\text { Very Involved: } 16.67 \% \\
\text { Somewhat Involved: } 56.25 \% \\
\text { Marginally Involved: } 22.92 \% \\
\text { Not Involved: } 4.17 \%\end{array}$ \\
\hline Master's Medium & $\begin{array}{l}\text { Very Involved: } 25.00 \% \\
\text { Somewhat Involved: } 47.73 \% \\
\text { Marginally Involved: } 18.18 \% \\
\text { Not Involved: } 9.09 \%\end{array}$ \\
\hline Master's Large & $\begin{array}{l}\text { Very Involved: } 4.55 \% \\
\text { Somewhat Involved: } 50.00 \% \\
\text { Marginally Involved: } 22.73 \% \\
\text { Not Involved: } 22.73 \%\end{array}$ \\
\hline Doctoral/Research & $\begin{array}{l}\text { Very Involved: } 50.00 \% \\
\text { Somewhat Involved: } 16.67 \% \\
\text { Marginally Involved: } 27.78 \% \\
\text { Not Involved: } 5.56 \%\end{array}$ \\
\hline $\begin{array}{l}\text { Research University } \\
\text { High }\end{array}$ & $\begin{array}{l}\text { Very Involved: } 29.41 \% \\
\text { Somewhat Involved: } 47.06 \% \\
\text { Marginally Involved: } 11.76 \% \\
\text { Not Involved: } 11.76 \%\end{array}$ \\
\hline $\begin{array}{l}\text { Research University } \\
\text { Very High }\end{array}$ & $\begin{array}{l}\text { Very Involved: } 36.84 \% \\
\text { Somewhat Involved: } 10.53 \% \\
\text { Marginally Involved: } 31.58 \% \\
\text { Not Involved: } 21.05 \%\end{array}$ \\
\hline \multicolumn{2}{|l|}{ Control } \\
\hline Public & $\begin{array}{l}\text { Very Involved: } 29.76 \% \\
\text { Somewhat Involved: } 39.29 \% \\
\text { Marginally Involved: } 19.05 \% \\
\text { Not Involved: } 11.90 \%\end{array}$ \\
\hline Private & $\begin{array}{l}\text { Very Involved: } 19.05 \% \\
\text { Somewhat Involved: } 46.43 \% \\
\text { Marginally Involved: } 25.00 \% \\
\text { Not Involved: } 9.52 \%\end{array}$ \\
\hline
\end{tabular}




\begin{tabular}{|c|c|}
\hline \multicolumn{2}{|c|}{$\begin{array}{l}\text { TABLE } 6 \\
\text { Perception of Library Involvement with Enrollment }(N=168)\end{array}$} \\
\hline & Responses \\
\hline \multicolumn{2}{|l|}{ Enrollment } \\
\hline 2,500 or fewer & $\begin{array}{l}\text { Very Involved: } 6.52 \% \\
\text { Somewhat Involved: } 28.26 \% \\
\text { Marginally Involved: } 39.13 \% \\
\text { Not Involved: } 26.09 \%\end{array}$ \\
\hline $2,500-6,000$ & $\begin{array}{l}\text { Very Involved: } 4.00 \% \\
\text { Somewhat Involved: } 32.00 \% \\
\text { Marginally Involved: } 36.00 \% \\
\text { Not Involved: } 28.00 \%\end{array}$ \\
\hline $6,000-12,000$ & $\begin{array}{l}\text { Very Involved: } 15.15 \% \\
\text { Somewhat Involved: } 30.30 \% \\
\text { Marginally Involved: } 36.36 \% \\
\text { Not Involved: } 18.18 \%\end{array}$ \\
\hline $12,000-18,000$ & $\begin{array}{l}\text { Very Involved: } 11.76 \% \\
\text { Somewhat Involved: } 41.18 \% \\
\text { Marginally Involved: } 29.41 \% \\
\text { Not Involved: } 17.65 \%\end{array}$ \\
\hline More than 18,000 & $\begin{array}{l}\text { Very Involved: } 13.64 \% \\
\text { Somewhat Involved: } 36.36 \% \\
\text { Marginally Involved: } 31.82 \% \\
\text { Not Involved: } 18.18 \%\end{array}$ \\
\hline \multicolumn{2}{|c|}{ Carnegie Classification } \\
\hline Master's Small & $\begin{array}{l}\text { Very Involved: } 4.17 \% \\
\text { Somewhat Involved: } 33.33 \% \\
\text { Marginally Involved: } 39.58 \% \\
\text { Not Involved: } 22.92 \%\end{array}$ \\
\hline Master's Medium & $\begin{array}{l}\text { Very Involved: } 15.91 \% \\
\text { Somewhat Involved: } 29.55 \% \\
\text { Marginally Involved: } 31.82 \% \\
\text { Not Involved: } 22.73 \%\end{array}$ \\
\hline Master's Large & $\begin{array}{l}\text { Very Involved: } 0.00 \% \\
\text { Somewhat Involved: } 31.82 \% \\
\text { Marginally Involved: } 40.91 \% \\
\text { Not Involved: } 27.27 \%\end{array}$ \\
\hline Doctoral/Research & $\begin{array}{l}\text { Very Involved: } 22.22 \% \\
\text { Somewhat Involved: } 22.22 \% \\
\text { Marginally Involved: } 38.89 \% \\
\text { Not Involved: } 16.67 \%\end{array}$ \\
\hline $\begin{array}{l}\text { Research University } \\
\text { High }\end{array}$ & $\begin{array}{l}\text { Very Involved: } 0.00 \% \\
\text { Somewhat Involved: } 41.18 \% \\
\text { Marginally Involved: } 35.29 \% \\
\text { Not Involved: } 23.53 \%\end{array}$ \\
\hline $\begin{array}{l}\text { Research University } \\
\text { Very High }\end{array}$ & $\begin{array}{l}\text { Very Involved: } 10.53 \% \\
\text { Somewhat Involved: } 36.84 \% \\
\text { Marginally Involved: } 26.32 \% \\
\text { Not Involved: } 26.32 \%\end{array}$ \\
\hline
\end{tabular}




\begin{tabular}{|l|l|}
\hline \multicolumn{2}{|c|}{ TABLE 6 } \\
\hline \multicolumn{2}{|c|}{ Perception of Library Involvement with Enrollment (N = 168) } \\
\hline Control & \multicolumn{2}{|c|}{ Very Involved: $10.71 \%$} \\
\hline Public & Somewhat Involved: $35.71 \%$ \\
& Marginally Involved: $34.52 \%$ \\
& Not Involved: $19.05 \%$ \\
\hline Private & Very Involved: $7.14 \%$ \\
& Somewhat Involved: $28.57 \%$ \\
& Marginally Involved: $36.90 \%$ \\
& Not Involved: $27.38 \%$ \\
\hline
\end{tabular}

\begin{tabular}{|c|c|}
\hline \multicolumn{2}{|c|}{$\begin{array}{c}\text { TABLE } 7 \\
\text { Perception of Library Involvement with Student Academic Success }(\mathrm{N}=168)\end{array}$} \\
\hline & Responses \\
\hline \multicolumn{2}{|l|}{ Enrollment } \\
\hline 2,500 or fewer & $\begin{array}{l}\text { Very Involved: } 30.43 \% \\
\text { Somewhat Involved: } 43.48 \% \\
\text { Marginally Involved: } 19.57 \% \\
\text { Not Involved: } 6.52 \%\end{array}$ \\
\hline $2,500-6,000$ & $\begin{array}{l}\text { Very Involved: } 30.00 \% \\
\text { Somewhat Involved: } 42.00 \% \\
\text { Marginally Involved: } 24.00 \% \\
\text { Not Involved: } 4.00 \%\end{array}$ \\
\hline $6,000-12,000$ & $\begin{array}{l}\text { Very Involved: } 33.33 \% \\
\text { Somewhat Involved: } 45.45 \% \\
\text { Marginally Involved: } 18.18 \% \\
\text { Not Involved: } 3.03 \%\end{array}$ \\
\hline $12,000-18,000$ & $\begin{array}{l}\text { Very Involved: } 41.18 \% \\
\text { Somewhat Involved: } 35.29 \% \\
\text { Marginally Involved: } 11.76 \% \\
\text { Not Involved: } 11.76 \%\end{array}$ \\
\hline More than 18,000 & $\begin{array}{l}\text { Very Involved: } 40.91 \% \\
\text { Somewhat Involved: } 36.36 \% \\
\text { Marginally Involved: } 18.18 \% \\
\text { Not Involved: } 4.55 \%\end{array}$ \\
\hline \multicolumn{2}{|c|}{ Carnegie Classification } \\
\hline Master's Small & $\begin{array}{l}\text { Very Involved: } 33.33 \% \\
\text { Somewhat Involved: } 39.58 \% \\
\text { Marginally Involved: } 22.92 \% \\
\text { Not Involved: } 4.17 \%\end{array}$ \\
\hline Master's Medium & $\begin{array}{l}\text { Very Involved: } 36.36 \% \\
\text { Somewhat Involved: } 40.91 \% \\
\text { Marginally Involved: } 18.18 \% \\
\text { Not Involved: } 4.55 \%\end{array}$ \\
\hline Master's Large & $\begin{array}{l}\text { Very Involved: } 9.09 \% \\
\text { Somewhat Involved: } 50.00 \% \\
\text { Marginally Involved: } 31.82 \% \\
\text { Not Involved: } 9.09 \%\end{array}$ \\
\hline
\end{tabular}




\begin{tabular}{|c|c|}
\hline \multicolumn{2}{|c|}{$\begin{array}{c}\text { TABLE } 7 \\
\text { Perception of Library Involvement with Student Academic Success }(\mathrm{N}=168)\end{array}$} \\
\hline Doctoral/Research & $\begin{array}{l}\text { Very Involved: } 61.11 \% \\
\text { Somewhat Involved: } 27.78 \% \\
\text { Marginally Involved: } 5.56 \% \\
\text { Not Involved: } 5.56 \%\end{array}$ \\
\hline $\begin{array}{l}\text { Research University } \\
\text { High }\end{array}$ & $\begin{array}{l}\text { Very Involved: } 17.65 \% \\
\text { Somewhat Involved: } 70.59 \% \\
\text { Marginally Involved: } 5.88 \% \\
\text { Not Involved: } 5.88 \%\end{array}$ \\
\hline $\begin{array}{l}\text { Research University } \\
\text { Very High }\end{array}$ & $\begin{array}{l}\text { Very Involved: } 42.11 \% \\
\text { Somewhat Involved: } 26.32 \% \\
\text { Marginally Involved: } 26.32 \% \\
\text { Not Involved: } 5.26 \%\end{array}$ \\
\hline \multicolumn{2}{|l|}{ Control } \\
\hline Public & $\begin{array}{l}\text { Very Involved: } 33.33 \% \\
\text { Somewhat Involved: } 44.05 \% \\
\text { Marginally Involved: } 17.86 \% \\
\text { Not Involved: } 4.76 \%\end{array}$ \\
\hline Private & $\begin{array}{l}\text { Very Involved: } 33.33 \% \\
\text { Somewhat Involved: } 39.29 \% \\
\text { Marginally Involved: } 21.43 \% \\
\text { Not Involved: } 5.95 \%\end{array}$ \\
\hline
\end{tabular}

\begin{tabular}{|c|c|}
\hline \multicolumn{2}{|c|}{$\begin{array}{l}\text { TABLE } 8 \\
\text { Perception of Library Involvement with Faculty Research Productivity }(\mathrm{N}=168)\end{array}$} \\
\hline & Responses \\
\hline \multicolumn{2}{|l|}{ Enrollment } \\
\hline 2,500 or fewer & $\begin{array}{l}\text { Very Involved: } 28.26 \% \\
\text { Somewhat Involved: } 50.00 \% \\
\text { Marginally Involved: } 21.74 \% \\
\text { Not Involved: } 0.00 \%\end{array}$ \\
\hline $2,500-6,000$ & $\begin{array}{l}\text { Very Involved: } 38.78 \\
\text { Somewhat Involved: } 42.86 \% \\
\text { Marginally Involved: } 18.37 \% \\
\text { Not Involved: } 0.00 \%\end{array}$ \\
\hline $6,000-12,000$ & $\begin{array}{l}\text { Very Involved: } 36.36 \% \\
\text { Somewhat Involved: } 51.52 \% \\
\text { Marginally Involved: } 12.12 \% \\
\text { Not Involved: } 0.00 \%\end{array}$ \\
\hline $12,000-18,000$ & $\begin{array}{l}\text { Very Involved: } 52.94 \% \\
\text { Somewhat Involved: } 41.18 \% \\
\text { Marginally Involved: } 5.88 \% \\
\text { Not Involved: } 0.00 \%\end{array}$ \\
\hline More than 18,000 & $\begin{array}{l}\text { Very Involved: } 81.82 \% \\
\text { Somewhat Involved: } 13.64 \% \\
\text { Marginally Involved: } 4.55 \% \\
\text { Not Involved: } 0.00 \%\end{array}$ \\
\hline
\end{tabular}




\begin{tabular}{|c|c|}
\hline \multicolumn{2}{|c|}{$\begin{array}{c}\text { TABLE } 8 \\
\text { Perception of Library Involvement with Faculty Research Productivity }(\mathrm{N}=168)\end{array}$} \\
\hline \multicolumn{2}{|c|}{ Carnegie Classification } \\
\hline Master's Small & $\begin{array}{l}\text { Very Involved: } 25.53 \% \\
\text { Somewhat Involved: } 51.06 \% \\
\text { Marginally Involved: } 23.40 \% \\
\text { Not Involved: } 0.00 \%\end{array}$ \\
\hline Master's Medium & $\begin{array}{l}\text { Very Involved: } 38.64 \% \\
\text { Somewhat Involved: } 40.91 \% \\
\text { Marginally Involved: } 20.45 \% \\
\text { Not Involved: } 0.00 \%\end{array}$ \\
\hline Master's Large & $\begin{array}{l}\text { Very Involved: } 22.73 \% \\
\text { Somewhat Involved: } 59.09 \% \\
\text { Marginally Involved: } 18.18 \% \\
\text { Not Involved: } 0.00 \%\end{array}$ \\
\hline Doctoral/Research & $\begin{array}{l}\text { Very Involved: } 50.00 \% \\
\text { Somewhat Involved: } 50.00 \% \\
\text { Marginally Involved: } 0.00 \% \\
\text { Not Involved: } 0.00 \%\end{array}$ \\
\hline $\begin{array}{l}\text { Research University } \\
\text { High }\end{array}$ & $\begin{array}{l}\text { Very Involved: } 70.59 \\
\text { Somewhat Involved: } 29.41 \% \\
\text { Marginally Involved: } 0.00 \% \\
\text { Not Involved: } 0.00 \%\end{array}$ \\
\hline $\begin{array}{l}\text { Research University } \\
\text { Very High }\end{array}$ & $\begin{array}{l}\text { Very Involved: } 84.21 \% \\
\text { Somewhat Involved: } 10.53 \% \\
\text { Marginally Involved: } 5.26 \% \\
\text { Not Involved: } 0.00 \%\end{array}$ \\
\hline \multicolumn{2}{|l|}{ Control } \\
\hline Public & $\begin{array}{l}\text { Very Involved: } 51.19 \% \\
\text { Somewhat Involved: } 33.33 \% \\
\text { Marginally Involved: } 15.48 \% \\
\text { Not Involved: } 0.00 \%\end{array}$ \\
\hline Private & $\begin{array}{l}\text { Very Involved: } 33.73 \% \\
\text { Somewhat Involved: } 51.81 \% \\
\text { Marginally Involved: } 14.46 \% \\
\text { Not Involved: } 0.00 \%\end{array}$ \\
\hline
\end{tabular}

\begin{tabular}{|l|l|}
\hline \multicolumn{2}{|c|}{ Perception of Library Involvement with Accreditation (N = 168) } \\
\hline \multicolumn{2}{|c|}{ Responses } \\
\hline Enrollment & \multicolumn{1}{|c|}{ TABLE 9 } \\
\hline 2,500 or fewer & $\begin{array}{l}\text { Very Involved: } 30.43 \% \\
\text { Somewhat Involved: } 52.17 \% \\
\\
\text { Marginally Involved: } 17.39 \% \\
\text { Not Involved: } 0.00 \%\end{array}$ \\
\hline $2,500-6,000$ & $\begin{array}{l}\text { Very Involved: } 40.00 \% \\
\text { Somewhat Involved: } 42.00 \% \\
\\
\end{array}$ \\
& Marginally Involved: $18.00 \%$ \\
& Not Involved: $0.00 \%$ \\
\hline
\end{tabular}




\begin{tabular}{|c|c|}
\hline \multicolumn{2}{|c|}{$\begin{array}{c}\text { TABLE } 9 \\
\text { Perception of Library Involvement with Accreditation }(\mathrm{N}=168)\end{array}$} \\
\hline $6,000-12,000$ & $\begin{array}{l}\text { Very Involved: } 30.30 \% \\
\text { Somewhat Involved: } 45.45 \% \\
\text { Marginally Involved: } 18.18 \% \\
\text { Not Involved: } 6.06 \%\end{array}$ \\
\hline $12,000-18,000$ & $\begin{array}{l}\text { Very Involved: } 41.18 \% \\
\text { Somewhat Involved: } 41.18 \% \\
\text { Marginally Involved: } 5.88 \% \\
\text { Not Involved: } 11.76 \%\end{array}$ \\
\hline More than 18,000 & $\begin{array}{l}\text { Very Involved: } 59.09 \% \\
\text { Somewhat Involved: } 31.82 \% \\
\text { Marginally Involved: } 9.09 \% \\
\text { Not Involved: } 0.00 \%\end{array}$ \\
\hline \multicolumn{2}{|c|}{ Carnegie Classification } \\
\hline Master's Small & $\begin{array}{l}\text { Very Involved: } 33.33 \% \\
\text { Somewhat Involved: } 47.92 \% \\
\text { Marginally Involved: } 18.75 \% \\
\text { Not Involved: } 0.00 \%\end{array}$ \\
\hline Master's Medium & $\begin{array}{l}\text { Very Involved: } 47.73 \% \\
\text { Somewhat Involved: } 38.64 \% \\
\text { Marginally Involved: } 9.09 \% \\
\text { Not Involved: } 4.55 \%\end{array}$ \\
\hline Master's Large & $\begin{array}{l}\text { Very Involved: } 36.36 \% \\
\text { Somewhat Involved: } 36.36 \% \\
\text { Marginally Involved: } 27.27 \% \\
\text { Not Involved: } 0.00 \%\end{array}$ \\
\hline Doctoral/Research & $\begin{array}{l}\text { Very Involved: } 38.89 \% \\
\text { Somewhat Involved: } 50.00 \% \\
\text { Marginally Involved: } 5.56 \% \\
\text { Not Involved: } 5.56 \%\end{array}$ \\
\hline $\begin{array}{l}\text { Research University } \\
\text { High }\end{array}$ & $\begin{array}{l}\text { Very Involved: } 23.53 \% \\
\text { Somewhat Involved: } 52.94 \% \\
\text { Marginally Involved: } 17.65 \% \\
\text { Not Involved: } 5.88 \%\end{array}$ \\
\hline $\begin{array}{l}\text { Research University } \\
\text { Very High }\end{array}$ & $\begin{array}{l}\text { Very Involved: } 42.11 \% \\
\text { Somewhat Involved: } 42.11 \% \\
\text { Marginally Involved: } 15.79 \% \\
\text { Not Involved: } 0.00 \%\end{array}$ \\
\hline \multicolumn{2}{|l|}{ Control } \\
\hline Public & $\begin{array}{l}\text { Very Involved: } 45.24 \% \\
\text { Somewhat Involved: } 36.90 \% \\
\text { Marginally Involved: } 14.29 \% \\
\text { Not Involved: } 3.57 \%\end{array}$ \\
\hline Private & $\begin{array}{l}\text { Very Involved: } 30.95 \% \\
\text { Somewhat Involved: } 51.19 \% \\
\text { Marginally Involved: } 16.67 \% \\
\text { Not Involved: } 1.19 \%\end{array}$ \\
\hline
\end{tabular}


Overall, public institution provosts tend to perceive academic libraries as being at least somewhat involved with student retention, student success, faculty research productivity, and accreditation and less involved in recruitment efforts. Public university provosts perceive the academic library organization as involved with many of the highimpact practices identified by Kuh, although less so for internships and service-learning initiatives. They tend to prioritize funding requests that are based upon correlational relationships between use of library services and retention, enrollment, and academic success of students, followed by endorsements from other deans or administrators and feedback from faculty. They would not prioritize a budget request based on anecdotal data. They prefer to have library information be communicated with them through formal annual reports or another dedicated presentation or meeting.

Private institution provosts share a number of similar perceptions of academic libraries with their counterparts in public universities. However, private institution provosts tend to perceive that their academic libraries have less involvement in undergraduate retention, although they are still largely seen as somewhat or marginally involved. Private institution provosts also tended to indicate that academic libraries at their institutions had more involvement in the high-impact practices of learning communities and capstone courses on their campuses and less involvement with service learning than what was shown by the public institution provosts. Further, private institution provosts tended to indicate that they were more likely to prioritize funding requests if they were based on correlational data to student success or retention, as well as correlational data to faculty research productivity. They prefer annual reports for most data, but indicated that e-mail or a dedicated presentation was more appropriate for endorsements from other deans or administrators, as well as for correlations demonstrating the relationship between library services and undergraduate retention and enrollment.

The distribution of answers tended to be consistent from provosts at institutions of different sizes, except for a few differences. More than 50 percent of provosts from institutions with enrollment greater than 6,000 perceive that academic libraries are very involved with faculty research productivity on their campuses. No provost at a large institution reported that academic libraries had no involvement in faculty research productivity, with only 8.3 percent saying they are only marginally involved. On the other hand, provosts from institutions with fewer than 6,000 students tend to perceive academic libraries as only somewhat or marginally involved with faculty research productivity. Likewise, larger institutions tended to indicate that academic libraries had more involvement with internships than smaller institutions. More than 46 percent of provosts from institutions with fewer than 6,000 students reported that academic libraries were not involved with internships, compared with less than 30 percent at larger institutions. More than 95 percent of provosts from larger institutions said that correlational data linking library services and resources with faculty research productivity would have moderate $(30.5 \%)$ or high $(65.2 \%)$ influence on prioritizing funding requests, compared with only 76 percent of provosts at smaller institutions $(42.7 \%$ moderate, and $34.3 \%$ high influence). Provosts from large institutions also preferred data to be shared in the annual budget presentation format more than did provosts from smaller institutions; however, this format always tended to be their second or third preference behind the formal annual report and a regular presentation or meeting.

There are some limitations to this study of note. The study's population-while large-did not include community colleges. The population of community college chief academic officers was excluded due to the significant differences between that population and those of four-year institutions. Regardless of whether any given fouryear institution is part of a statewide system or an institution with its own governing 
TABLE 10

Summary of Library Value Data's Influence on Funding Requests \& Preferred Method of Communication

\begin{tabular}{|c|c|c|c|c|c|}
\hline & $\begin{array}{c}\text { Influence } \\
\quad \text { on } \\
\text { Budget } \\
\text { Request }\end{array}$ & $\begin{array}{c}\begin{array}{c}\text { Percentage } \\
\text { of Provosts } \\
\text { Selecting } \\
\text { Influence } \\
\text { Level }\end{array} \\
\end{array}$ & $\begin{array}{c}\text { Notable } \\
\text { Differences }\end{array}$ & $\begin{array}{c}\text { Public } \\
\text { Institution } \\
\text { Communication } \\
\text { Preference }\end{array}$ & $\begin{array}{c}\text { Private } \\
\text { Institution } \\
\text { Communication } \\
\text { Preference }\end{array}$ \\
\hline $\begin{array}{l}\text { Student } \\
\text { Academic } \\
\text { Success }\end{array}$ & High & 72.02 & $\begin{array}{l}\text { DRU: higher } \\
\text { influence }\end{array}$ & Annual Report & $\begin{array}{l}\text { Presentation or } \\
\text { meeting }\end{array}$ \\
\hline $\begin{array}{l}\text { Undergraduate } \\
\text { Retention }\end{array}$ & High & 66.07 & $\begin{array}{l}\text { DRU: higher } \\
\text { influence }\end{array}$ & Annual Report & $\begin{array}{l}\text { Presentation or } \\
\text { meeting }\end{array}$ \\
\hline Enrollment & High & 56.55 & None & Annual Report & $\begin{array}{l}\text { Presentation or } \\
\text { meeting }\end{array}$ \\
\hline $\begin{array}{l}\text { Faculty } \\
\text { Research } \\
\text { Productivity }\end{array}$ & High & 47.62 & $\begin{array}{l}\text { DRU \& } \\
\text { Research: } \\
\text { higher } \\
\text { influence } \\
\text { Master's } \\
\text { Medium \& } \\
\text { Small: lower } \\
\text { influence }\end{array}$ & Annual Report & $\begin{array}{l}\text { Presentation or } \\
\text { meeting }\end{array}$ \\
\hline $\begin{array}{l}\text { Endorsement } \\
\text { of Request }\end{array}$ & High & 47.62 & $\begin{array}{l}\text { DRU \& } \\
\text { Research: } \\
\text { higher } \\
\text { influence }\end{array}$ & $\begin{array}{l}\text { Presentation or } \\
\text { meeting; E-mail }\end{array}$ & $\begin{array}{l}\text { Presentation or } \\
\text { meeting; E-mail }\end{array}$ \\
\hline $\begin{array}{l}\text { Basic } \\
\text { Utilization } \\
\text { Data }\end{array}$ & Moderate & 57.14 & None & Annual Report & Annual Report \\
\hline $\begin{array}{l}\text { User } \\
\text { Satisfaction }\end{array}$ & Moderate & 55.36 & None & Annual Report & Annual Report \\
\hline Focus Groups & Moderate & 50.00 & $\begin{array}{l}\text { DRU: higher } \\
\text { influence } \\
\text { Master's } \\
\text { Small: lower } \\
\text { influence }\end{array}$ & No data & No data \\
\hline $\begin{array}{l}\text { Info. Lit. SLO } \\
\text { Data }\end{array}$ & Moderate & 48.21 & $\begin{array}{l}\text { Master's } \\
\text { Medium: } \\
\text { higher } \\
\text { influence }\end{array}$ & Annual Report & Annual Report \\
\hline $\begin{array}{l}\text { Faculty } \\
\text { Feedback }\end{array}$ & Moderate & 45.24 & $\begin{array}{l}\text { DRU: higher } \\
\text { influence }\end{array}$ & Annual Report & Annual Report \\
\hline $\begin{array}{l}\text { Anecdotal } \\
\text { Evidence }\end{array}$ & Low & 60.12 & $\begin{array}{l}27.38 \text { selected } \\
\text { no influence }\end{array}$ & $\begin{array}{l}\text { Presentation or } \\
\text { meeting }\end{array}$ & $\begin{array}{l}\text { Presentation or } \\
\text { meeting }\end{array}$ \\
\hline
\end{tabular}


board, institutions in the master's (small, medium, and large), DRU, and research classifications have an identifiable chief academic officer per institution. This is not the case with community colleges, making the identification of potential participants problematic. Additionally, the survey questions were written assuming a traditional four-year college experience, particularly the questions on the HIPs. The HIPs are primarily oriented to undergraduates; and, not only do they not account for the experiences of two-year college students, they also do not accommodate the experiences of students in professional or graduate programs. The perspective of chief academic officers on library value for community college initiatives or for the graduate/professional degree experience represents areas for future study.

\section{Conclusion}

As the authors noted in their previous article on the development of reciprocal value propositions, the impetus behind the many emerging studies on academic library value is distinctly political: to maintain or improve library funding, to position the academic library favorably in renovation or capital construction planning, and to otherwise demonstrate the ongoing relevance of the library to the overall university. ${ }^{26}$ This political undertaking has a variety of potential stakeholders or allies, primary among them the provost or chief academic officer. Since the study conducted by Lynch et al., there had been no recent examination of provosts' perceptions of the library, and no large-scale study had been conducted. It is therefore imperative to have an improved understanding of provosts' perceptions of library participation in university initiatives, the types of data that will sway provosts to support library budget requests, and how they prefer those data be communicated.

Overall, provosts or chief academic officers indicate that academic libraries are involved with important campus initiatives such as student retention and success, faculty research productivity, and accreditation. They also tend to note that the biggest barrier for academic libraries to be involved with campus initiatives is that the campus overall doesn't recognize that potential. When asked "are there specific library services, resources, or practices that stand out as evidence" of involvement with Kuh's highimpact practices, provosts provided examples that broadly championed the academic library trifecta: space, staffing and instructional outreach, and resources. However, this research supports the conclusions found by Lynch et al. ${ }^{27}$ Academic libraries are no longer the symbolic "heart of the university"; instead, they must provide evidence to support funding requests that support the priorities of the institution as a whole. Further, library administrators have higher impact when communicating that evidence with provosts and other institutional administrators through means that are timely and relevant, such as a formal annual report or a dedicated budget meeting. Library administrators must strategically use endorsements from deans, directors, or other administrators, as well as user satisfaction data. While basic use data such as visitor or download counts still have some influence, these types of data pale in comparison to the more emphatic influence garnered by correlational data to retention, success, and even evidence of learning information literacy skills. Library administrators must look to anecdotal or qualitative evidence sparingly alongside a suite of communication declaring explicit evidence of impact. 


\section{Appendix A. Provost Study}

Q1 Welcome to the Survey for Provosts' Perceptions of the University Library's Role in High-Impact Practices. Adam Murray of James Madison University and Ashley Ireland of Murray State University invite you to participate in a research study that looks at the perceptions that Provosts have on the role academic libraries play in highimpact practices, as well as the impact that role may have on budgetary requests. The purpose of the study is to examine ways in which Provosts prefer to receive communications about library contributions toward institutional priorities. You will be asked to fill out this survey now, and once again in a few weeks. To configure this survey appropriately, the instrument also contains four questions that will allow us to match responses while ensuring your anonymity. We expect this survey to take 10 to 15 minutes to complete. This survey is anonymous. While you may not receive any direct benefit for participating, we hope that this study will contribute to the communication between Library Deans or Directors and their Provosts. Participating in this study is completely voluntary. Even if you decide to participate now, you may change your mind and stop at any time.

Q2 Select your institution type (Carnegie classification).

․ Master's College or University Small (Master's S) (1)

Master's College or University Medium (Master's M) (2)

Master's College or University Large (Master's L) (3)

$\square \quad$ Doctoral/Research University (DRU) (4)

$\square \quad$ Research University High (RU/H) (5)

$\square \quad$ Research University Very High (RU/VH) (6)

Q3 What is your institution's current undergraduate enrollment?

2,500 or less (1)

$\square \quad 2,500-6,000(2)$

$\square \quad 6,000-12,000(3)$

12,000-18,000 (4)

․ More than $18,000(5)$

Q14 Is your institution a public institution or a private institution?

$\square \quad$ Public (1)

$\square \quad$ Private (2)

Q4 Select your regional accrediting agency.

$\square \quad$ Middle States Commission on Higher Education (MSCHE) (1)

$\square \quad$ New England Association of Schools and Colleges Commission on Institutions of Higher Education (NEASC-CIHE) (2)

$\square \quad$ North Central Association of Colleges and Schools-The Higher Learning Commission (NCA-HLC) (3)

$\square \quad$ Southern Association of Colleges and Schools Commission on Colleges (SACS-COC) (4)

$\square \quad$ Western Association of Schools and Colleges Senior College and University Commission (WASC-SCUC) (5)

$\square \quad$ Northwest Commission of Colleges and Universities (NWCCU) (6)

Q5 Select the faculty status of librarians at your current institution. Select all that apply.

$\square \quad$ Professional or Classified Staff (1)

$\square \quad$ Faculty, with eligibility for tenure (2) 
$\square \quad$ Faculty, not eligible for tenure (3)

Q6 How involved do you perceive your institution's academic library to be in:

\begin{tabular}{|c|c|c|c|c|c|}
\hline & $\begin{array}{l}\text { Very } \\
\text { Involved (1) }\end{array}$ & $\begin{array}{l}\text { Somewhat } \\
\text { Involved (2) }\end{array}$ & $\begin{array}{l}\text { Marginally } \\
\text { Involved (3) }\end{array}$ & $\begin{array}{l}\text { Not Involved } \\
\text { (4) }\end{array}$ & N/A (5) \\
\hline $\begin{array}{l}\text { Undergraduate } \\
\text { Retention } \\
\text { Initiatives (1) }\end{array}$ & 0 & 0 & 0 & 0 & 0 \\
\hline $\begin{array}{l}\text { Enrollment } \\
\text { Initiatives (2) }\end{array}$ & 0 & 0 & 0 & 0 & 0 \\
\hline $\begin{array}{l}\text { Student } \\
\text { Academic } \\
\text { Success } \\
\text { (GPA or other } \\
\text { indicators) (3) }\end{array}$ & O & 0 & 0 & 0 & 0 \\
\hline $\begin{array}{l}\text { Faculty } \\
\text { Research } \\
\text { Productivity } \\
\text { (4) }\end{array}$ & O & O & O & O & 0 \\
\hline $\begin{array}{l}\text { Accreditation } \\
\text { (5) }\end{array}$ & $\mathrm{O}$ & $\mathrm{O}$ & $\mathrm{O}$ & 0 & $\mathrm{O}$ \\
\hline
\end{tabular}

Q7 If you do not view your institution's academic library as being involved with undergraduate retention initiatives, please indicate why (select all that apply):

$\square \quad$ the library dean has not prioritized participation in retention (1)

$\square \quad$ the library is short-staffed (2)

$\square \quad$ retention initiatives are not an institutional priority (3)

$\square \quad$ the campus overall does not recognize the role the library could play in retention initiatives (4)

$\square \quad$ Other (please describe) (5)

Q8 How involved is your institution's academic library with each of the following high-impact practices?

\begin{tabular}{|c|c|c|c|c|c|c|}
\hline & \begin{tabular}{|l|} 
Very \\
Involved \\
$(1)$ \\
\end{tabular} & $\begin{array}{l}\text { Somewhat } \\
\text { Involved } \\
(2)\end{array}$ & $\begin{array}{l}\text { Marginally } \\
\text { Involved } \\
(3)\end{array}$ & $\begin{array}{l}\text { Not } \\
\text { Involved } \\
(4)\end{array}$ & N/A (5) & $\begin{array}{l}\text { Unknown } \\
\text { (6) }\end{array}$ \\
\hline $\begin{array}{l}\text { First-year } \\
\text { seminars and } \\
\text { first-year } \\
\text { experiences (1) }\end{array}$ & O & O & O & $\bigcirc$ & O & O \\
\hline $\begin{array}{l}\text { Common } \\
\text { intellectual } \\
\text { (curricular or } \\
\text { cocurricular) } \\
\text { experiences (2) }\end{array}$ & O & O & O & O & O & O \\
\hline
\end{tabular}




\begin{tabular}{|l|c|c|c|c|c|c|}
\hline $\begin{array}{l}\text { Learning } \\
\text { communities } \\
\text { (3) }\end{array}$ & $\bigcirc$ & $\bigcirc$ & $\bigcirc$ & $\bigcirc$ & $\bigcirc$ & $\bigcirc$ \\
\hline $\begin{array}{l}\text { Writing- } \\
\text { intensive } \\
\text { courses (4) }\end{array}$ & $\bigcirc$ & $\bigcirc$ & $\bigcirc$ & $\bigcirc$ & $\bigcirc$ & $\bigcirc$ \\
\hline $\begin{array}{l}\text { Collaborative } \\
\text { assignments \& } \\
\text { projects (5) }\end{array}$ & $\bigcirc$ & $\bigcirc$ & $\bigcirc$ & $\bigcirc$ & $\bigcirc$ & $\bigcirc$ \\
\hline $\begin{array}{l}\text { Undergraduate } \\
\text { research (6) }\end{array}$ & $\bigcirc$ & $\bigcirc$ & $\bigcirc$ & $\bigcirc$ & $\bigcirc$ & $\bigcirc$ \\
\hline $\begin{array}{l}\text { Diversity \& } \\
\text { global learning } \\
\text { (7) }\end{array}$ & $\bigcirc$ & $\bigcirc$ & $\bigcirc$ & $\bigcirc$ & $\bigcirc$ & $\bigcirc$ \\
\hline $\begin{array}{l}\text { Service learning } \\
\text { community- } \\
\text { based learning } \\
\text { (8) }\end{array}$ & $\bigcirc$ & $\bigcirc$ & $\bigcirc$ & $\bigcirc$ & $\bigcirc$ & $\bigcirc$ \\
\hline Internships (9) & $\bigcirc$ & $\bigcirc$ & $\bigcirc$ & $\bigcirc$ & $\bigcirc$ & $\bigcirc$ \\
\hline $\begin{array}{l}\text { Capstone } \\
\text { courses \& } \\
\text { projects (10) }\end{array}$ & $\bigcirc$ & $\bigcirc$ & $\bigcirc$ & $\bigcirc$ & $\bigcirc$ & $\bigcirc$ \\
\hline
\end{tabular}

Q9 Are there specific library services, resources, or practices that stand out as evidence of involvement with the following high-impact practices? Examples of this could include library instructional practices or use of the physical spaces in the library.

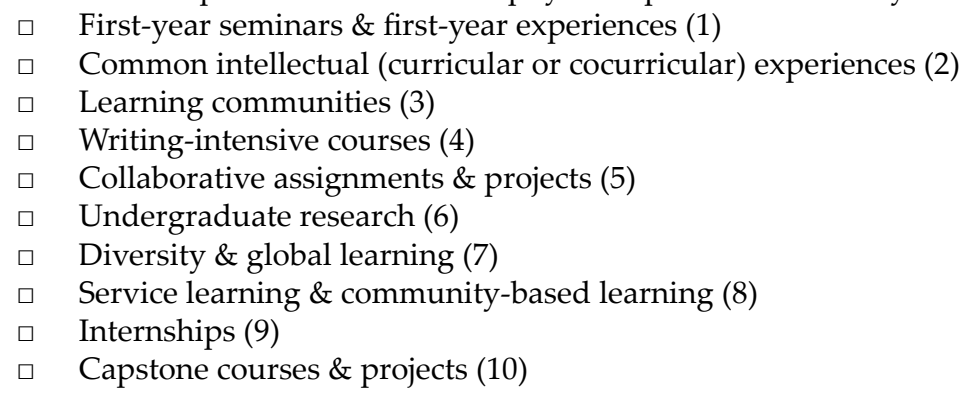

Q10 In your view, does your institution's academic library have an impact on students' decisions to continue enrollment?
$\square \quad$ Yes: based on demonstrated evidence (1)
$\square \quad$ Yes: based on anecdotal or suspected evidence (2)
$\square \quad$ Unclear (3)
$\square \quad$ No (4)

Q11 Suppose your institution's library dean or director approached you with a moderate (noncapital) funding request, such as for new positions or an increase in the collections budget, that competed with funding requests from other (revenue-generating) academic units. Please rate the influence each of the following types of data would have on your prioritization of the library's funding request over those of the other academic units. 
No influence $=$ I would definitely not prioritize this request Low influence $=$ I would probably not prioritize the request Moderate influence $=$ I would consider prioritizing the request High influence $=\mathrm{I}$ would prioritize the request over others

\begin{tabular}{|c|c|c|c|c|}
\hline & $\begin{array}{l}\text { No Influence } \\
\text { (1) }\end{array}$ & $\begin{array}{l}\text { Low } \\
\text { Influence (2) }\end{array}$ & $\begin{array}{l}\text { Moderate } \\
\text { Influence (3) }\end{array}$ & $\begin{array}{l}\text { High } \\
\text { Influence (4) }\end{array}$ \\
\hline $\begin{array}{l}\text { Basic utilization data, } \\
\text { such as door counts or } \\
\text { download counts }(1)\end{array}$ & ○ & $\bigcirc$ & $\bigcirc$ & O \\
\hline User satisfaction data (2) & $\mathrm{O}$ & $\mathrm{O}$ & $\mathrm{O}$ & $\mathrm{O}$ \\
\hline Faculty feedback (3) & O & $\mathrm{O}$ & $\mathrm{O}$ & O \\
\hline $\begin{array}{l}\text { Endorsement of the request } \\
\text { by other deans, directors, } \\
\text { or administrators (4) }\end{array}$ & O & O & ○ & ○ \\
\hline $\begin{array}{l}\text { Demonstrated correlations } \\
\text { linking use of library } \\
\text { services/resources with } \\
\text { undergraduate retention (5) }\end{array}$ & O & O & O & O \\
\hline $\begin{array}{l}\text { Demonstrated correlations } \\
\text { linking library services/ } \\
\text { resources with enrollment } \\
\text { (6) }\end{array}$ & O & O & O & O \\
\hline $\begin{array}{l}\text { Demonstrated correlations } \\
\text { linking use of library } \\
\text { services/resources with } \\
\text { student academic success } \\
\text { (7) }\end{array}$ & O & O & O & O \\
\hline $\begin{array}{l}\text { Demonstrated correlations } \\
\text { linking use of library } \\
\text { services/resources } \\
\text { with faculty research } \\
\text { productivity (8) }\end{array}$ & O & O & O & O \\
\hline $\begin{array}{l}\text { Focus groups or other } \\
\text { qualitative data (9) }\end{array}$ & O & O & O & O \\
\hline Anecdotal evidence (10) & O & $\bigcirc$ & O & O \\
\hline $\begin{array}{l}\text { Information literacy } \\
\text { student learning outcome } \\
\text { assessment data (11) }\end{array}$ & $\mathrm{O}$ & $\mathrm{O}$ & $\mathrm{O}$ & $\mathrm{O}$ \\
\hline
\end{tabular}

Q13 What would be the most effective method of communicating each of the following types of data with you in a way that would most likely improve library funding? 


\begin{tabular}{|c|c|c|c|c|c|}
\hline & $\begin{array}{l}\text { Formal } \\
\text { annual } \\
\text { report } \\
(1)\end{array}$ & $\begin{array}{l}\text { Annual } \\
\text { budget } \\
\text { presentation } \\
\text { (2) }\end{array}$ & $\begin{array}{l}\text { E-mail } \\
(3)\end{array}$ & $\begin{array}{l}\text { Presentation } \\
\text { or meeting } \\
(4)\end{array}$ & $\begin{array}{l}\text { This type of } \\
\text { data has little } \\
\text { influence on } \\
\text { improving } \\
\text { library } \\
\text { funding (5) }\end{array}$ \\
\hline $\begin{array}{l}\text { Basic utilization data, such } \\
\text { as door counts or download } \\
\text { counts (1) }\end{array}$ & ○ & ○ & O & ○ & $\bigcirc$ \\
\hline User satisfaction data (2) & O & O & O & O & O \\
\hline Faculty feedback (3) & O & O & O & O & O \\
\hline $\begin{array}{l}\text { Endorsement of the request } \\
\text { by other deans, directors, or } \\
\text { administrators (4) }\end{array}$ & O & O & O & O & O \\
\hline $\begin{array}{l}\text { Demonstrated correlations } \\
\text { linking use of library } \\
\text { services/resources with } \\
\text { undergraduate retention (5) }\end{array}$ & O & O & O & O & $\mathrm{O}$ \\
\hline $\begin{array}{l}\text { Demonstrated correlations } \\
\text { linking library services/ } \\
\text { resources with enrollment } \\
(6)\end{array}$ & O & O & O & O & O \\
\hline $\begin{array}{l}\text { Demonstrated correlations } \\
\text { linking use of library } \\
\text { services/resources with } \\
\text { student academic success } \\
\text { (7) }\end{array}$ & O & O & O & O & O \\
\hline $\begin{array}{l}\text { Demonstrated correlations } \\
\text { linking use of library } \\
\text { services/resources } \\
\text { with faculty research } \\
\text { productivity ( } 8 \text { ) }\end{array}$ & O & O & O & O & $\bigcirc$ \\
\hline $\begin{array}{l}\text { Qualitative or anecdotal } \\
\text { data (9) }\end{array}$ & O & O & O & O & O \\
\hline $\begin{array}{l}\text { Information literacy } \\
\text { student learning outcome } \\
\text { assessment data (10) }\end{array}$ & O & O & O & O & O \\
\hline
\end{tabular}

Q14 Thank you for your participation. If you would like to receive a synopsis of this study's findings, please enter your e-mail below.

\section{Notes}

1. Jon McGee, Breakpoint: The Changing Marketplace for Higher Education (Baltimore, Md.: Johns Hopkins University Press, 2015).
2. Ibid., 32 .
3. Ibid., 49 .
4. Ibid., 68 .
5. Ibid., 7. 
6. Beverly Lynch, Catherine Murray-Rust, Susan Parker, Deborah Turner, Diane Parr Walker, Frances Wilkinson, and Julia Zimmerman, "Attitudes of Presidents and Provosts on the University Library," College \& Research Libraries 68, no. 3 (2007): 213-27; OCLC. OCLC, At a Tipping Point: Education, Learning and Libraries (2014), 70.

7. ACRL Value of Academic Libraries, available online at www.acrl.ala.org/value/ [accessed 6 March 2018].

8. Jody Condit Fagan, "The Effectiveness of Academic Library Deans and Directors: A Literature Review," Library Leadership \& Management 26, no. 1 (2012): 2.

9. Megan Oakleaf, Value of Academic Libraries: A Comprehensive Research Review and Report (Chicago, Ill.: American Library Association, 2010), 267.

10. Elizabeth M. Mezick, "Relationship of Library Assessment to Student Retention," Journal of Academic Librarianship 41 (2015): 35.

11. Barbara I. Dewey, "Leading the Library by Leading the Campus: A Dean's Perspective," Library Leadership E Management 29, no. 1 (2014): 1-10.

12. John J. Meier, “The Future of Academic Libraries: Conversations with Today's Leaders about Tomorrow," portal: Libraries and the Academy 16, no. 2 (2016): 267.

13. Ibid., 268.

14. Lee G. Bolman and Terrance E. Deal, Reframing Organizations, Fifth Edition (San Fransisco, Calif.: Jossey-Bass, 2013).

15. Rachel A. Fleming-May and Kimberly Douglass, "Framing Librarianship in the Academy: An Analysis Using Bolman and Deal's Model of Organizations," College E Research Libraries 75, no. 3 (2014): 389-415.

16. Ibid., 392.

17. Ibid., 411.

18. Colleen Boff, "A Quantitative Study of Academic Library Administrators Using Bolman and Deal's Leadership Orientation Framework" (PhD diss., Bowling Green State University, 2015), 71.

19. Ibid., 98-99.

20. Ibid., 98 .

21. Lynch et al., "Attitudes of Presidents and Provosts on the University Library."

22. Ibid., 226.

23. Ibid., 227.

24. Murray, Adam L., and Ashley P. Ireland. "Communicating Library Impact on Retention: A Framework for Developing Reciprocal Value Propositions," Journal of Library Administration 57, no. 3 (2017): 311-326.

25. George Kuh, "High-Impact Educational Practices: What They Are, Who Has Access to Them, and Why They Matter" (Washington, D.C.: Association of American Colleges and Universities, 2008).

26. Murray and Ireland, "Communicating Library Impact on Retention."

27. Lynch et al., "Attitudes of Presidents and Provosts on the University Library." 